\title{
EL MOTÍN DE ALDEANUEVA DE EBRO DE 1663: UN MOVIMIENTO ANTIOLIGÁRQUICO Y ANTISEÑORIAL
}

\author{
Pedro Luis Lorenzo Cadarso \\ Universidad de Extremadura \\ plorenzo@alcazaba.unex.es
}

RESUMEN: Hacemos un análisis detallado del contexto y el desarrollo de un motín antioligárquico y antiseñorial que se produjo en Aldeanueva de Ebro (La Rioja) en 1663. El objetivo es demostrar como tras una aparente explosión de cólera colectiva, lo que realmente sucede es una planificación y una organización racional del movimiento, diseñado en términos estratégicos y ejecutado con absoluta disciplina por los amotinados.

Palabras clave: Motín, movimientos sociales, protesta popular, lucha antiseñorial.

\section{THE RIOTS OF ALDEANUEVA DE EBRO IN 1663: AN ANTI-OLIGARCHIC AND ANTISEIGNEURIAL MOVEMENT}

\begin{abstract}
We're making a detailed analysis about the context and the progress of the antioligarchical and antilordy mutiny that took place in Aldeanueva de Ebro (La Rioja) in 1663. The main goal is to prove that behind an apparent collective anger explosion, what's really happening is a rational planned and organized movement, designed in strategic terms and executed with absolute discipline by all the mutineers.
\end{abstract}

Keywords: Riot, social movements, popular protest, antilordy struggle.

Recibido: 6 de mayo de 2017

Aceptado: 8 de Junio de 2017 
Todo había comenzado muy lejos de Aldeanueva y muchos años atrás, en 1635, cuando Luis XIII de Francia declaró la guerra a España, después de que los Tercios derrotasen a los suecos en Nördlingen (1634) y se hiciera patente el riesgo de que los españoles se adueñasen de Alemania. La situación de la Hacienda Real ya era desesperada antes de que se le abriera este nuevo frente de batalla y no tardó en empeorar, así que un acuerdo de Cortes, formalizado en $1639^{1}$, autorizó al rey para vender a señores particulares 8.000 vasallos de realengo. Este tipo de operaciones estaban prohibidas por ley desde el siglo XIII, desde la época de Alfonso X el Sabio, pero todos los reyes, de un modo u otro, las habían hecho, alegando siempre, claro está, "circunstancias excepcionales" ${ }^{\prime 2}$. Durante bastante tiempo nada pareció indicar que Aldeanueva se fuese a ver directamente afectada por los problemas financieros de la Corona, pero ya en 1654, durante la operaciones financieras para superar la bancarrota de la Hacienda de 1652, comenzaron a notarse: el rey vendió a Francisco Manso de Zúñiga, Arzobispo de Burgos y el año anterior nombrado Conde de Hervías, las alcabalas, las tercias y los unos por ciento de Aldeanueva, tres de los impuestos que los vecinos pagaban a la Corona, valorados en 272.184 maravedís al año, por los cuales el Conde-Obispo pagó, aproximadamente, la recaudación de unos 40 años ${ }^{3}$; y la privatización de los impuestos implicaba siempre métodos recaudatorios mucho menos condescendientes que los empleados hasta entonces por la Corona.

Conviene aclarar que las ventas de vasallos que se hicieron al amparo de este acuerdo de Cortes fueron distintas a las realizadas hasta el siglo XVI. Tradicionalmente, quien recibía el señorío sobre una población estaba obligado a respetar las costumbres de autogobierno que rigiesen en el lugar, puesto que el rey sólo transfería al Señor los derechos que hasta entonces viniese ejerciendo directamente la Corona. Sin embargo ahora, al objeto de hacer las ventas más atractivas para los compradores, se otorgaba al nuevo Señor el derecho a designar unilateralmente a las autoridades políticas del concejo -regidores-y

1. Este acuerdo de Cortes contradecía otros anteriores de 1601 y 1635, que prohibían taxativamente la venta de villazgos a las aldeas. Cfr. Gelabert González, J. E., La bolsa del rey. Rey, reino y fisco en Castilla (1598-1648), Barcelona, 1997, p. 205.

2. Sobre el tema de la enajenación de aldeas de realengo, véase el clásico Domínguez Ortiz, A., "Ventas y exenciones de lugares durante el reinado de Felipe IV", en $A H D E$, tomo XXXIV, 1964, pp. 163-207; o bien un estado de la cuestión en Truchuelo García, Susana, "Villas y aldeas en el Antiguo Régimen: conflicto y consenso en el marco local castellano", en Mundo Agrario, vol. 14, no 27; Marcos Martín, A., "Enajenaciones por precio del patrimonio regio en los siglos XVI y XVII. Balance historiográfico y perspectivas de análisis", en Balance de la historiografía modernista. 1973-2001, Santiago de Compostela, 2003, pp. 418-443, y Soria Mesa, E., "La ruptura del orden jurisdiccional en la Castilla de los Austrias. Una interpretación", en Guillamón Álvarez, F. J. y Ruiz Ibáñez, J. J. (eds.) Lo conflictivo y lo consensual en Castilla: sociedad y poder político: 1521-1715, Murcia, 2001, pp. 441-458.

3. Vicuña, Javier, "El motín de Aldeanueva", en Berceo, nº 102, 1982, p. 75. 
judiciales -alcaldes-, con lo que desaparecían las tradiciones locales de autogobierno que existiesen. Para Aldeanueva esto suponía que desaparecían los concejos abiertos y la elección de la corporación municipal por los propios vecinos.

Aldeanueva era, ciertamente, una aldea de Calahorra, pero se encontraba en una situación relativamente excepcional por dos razones. La primera -que tendría consecuencias trágicas- era que en ella residían unas élites locales de un nivel muy superior al que era usual en otras aldeas, sobre todo los Ruiz de Bucesta $^{4}$, una poderosa familia, rica y bien relacionada con buena parte de los linajes más influyentes de La Rioja. La segunda era que sus condiciones políticas y económicas poco tenían que ver con la situación de sometimiento en la que solían encontrarse las aldeas españolas de la época.

Ordinariamente, el gobierno político y económico efectivo de las aldeas se hacía desde la villa o ciudad de la que dependían, lo cual daba pie a todo tipo de abusos, y lo mismo sucedía con la autoridad judicial, que en las aldeas quedaba reducida a un par de jurados con unas competencias jurisdiccionales reducidísimas. Pero en el caso de Aldeanueva -y lo mismo en las demás aldeas de Calahorra ${ }^{5}$ no era del todo así, pues cada año elegían 2 regidores, 4 diputados y 2 alcaldes ordinarios -o jueces de primera instancia-, situación de todo punto anómala, pues las aldeas no tenían jurisdicción propia, y por lo tanto no tenían derecho a elegir regidores ni mucho menos alcaldes ${ }^{6}$. Además, cada una de las aldeas de Calahorra disponía de sus propias infraestructuras de riego, que gestionaba autónomamente, y sus vecinos podían acceder en igualdad de condiciones con los de Calahorra a los pastos comunales de la ciudad ${ }^{7}$.

El autogobierno del pueblo se hacía a partir de llamado concejo abierto, una asamblea de vecinos - varones y mayores de edad- en la que todos tenían voz y voto en régimen de igualdad. En estas asambleas se tomaban las grandes decisiones políticas y económicas y cada año se elegían por votación a los cargos públicos. Este régimen de gobierno era muy peligroso para la Corona y para los señores de vasallos, que tropezaban con muchas dificultades para controlar políticamente a los concejos, pero también era inadecuado para las élites locales, cuya autoridad se veía enormemente mermada. Desde el siglo XIV la Corona y

4. Sobre esta familia, véase Ruiz de Bucesta, Manuel, "Aldeanueva. Armas vivas. Armas perdidas", en Boletín de la Asociación Riojana de Genealogía y Heráldica, n 2, 2010, pp. 6-17.

5. Por estas fechas eran también aldeas de Calahorra las poblaciones de Murillo, Rincón de Soto, Torroba, Velilla, Pradejón y San Felices.

6. Los alcaldes de Aldeanueva podían instruir, por un Privilegio Real, procesos civiles tasados hasta en 4.000 mrs., Vid. AHPLo., Legajo 6.346, 1641, Folio 216-217, doc. proporcionado por $\mathrm{D}^{\mathrm{a}}$ Sara Bustos.

7. La reconstrucción del sistema de gobierno en Aldeanueva y la gestión de los comunales de Calahorra a comienzos del siglo XVII puede verse en A.H.N., Sección Consejos, legajo $\mathrm{n}^{\circ}$ 25.434 . 
los señores, con el apoyo de esas oligarquías, fueron sustituyendo los concejos abiertos por ayuntamientos o concejos cerrados, en los que ya sólo participaban los alcaldes y los regidores, elegidos directamente por el Rey y los señores o bien mediante votaciones en las que sólo participaba la corporación saliente. En cualquier caso, el pueblo Ilano quedaba excluido del gobierno municipal. Si Aldeanueva era vendida a un Señor, éste adquiriría el derecho a designar a los miembros del Ayuntamiento y, lógicamente, el régimen de concejo abierto desaparecería. No se trataba de un riesgo específico de Aldeanueva, sino una realidad constatable en cientos de segregaciones hechas desde el reinado de Felipe $\mathrm{II}^{8}$, como denunciaba el corregidor de Quesada en la época en que se intentaría la de Aleanueva:

Las exempciones... de las ciudades y villas realengas... han puesto en miserable estado las villas a quienes se les ha concedido, porque se han alzado con el mando una o dos familias o los más poderosos. Vinculando en sí sus casas, hermanos, parientes y amigos, las varas y el gobierno, castigan al que no lo es, hacen lo que quieren los que son de los suyos y todos mandan, hasta las mujeres... Cométense muchos robos, muertes y otros atrocísimos delitos, paséanse a vista de los ofendidos, cómense sus ganados los panes, talan los montes, no pagan cosa que considerable sea, mézclanse en las rentas reales, vuélvanse a repartir, maltratan y echan del lugar al que se les opone. Nadie habla ni se atreve, con que recae todo sobre el pobre ${ }^{9}$.

En consecuencia, a los vecinos la venta de su pueblo, por mucho que pasasen a convertirse en villa, no les iba a reportar sino perjuicios económicos y políticos, luego continuar siendo una aldea era la mejor de las opciones. Había un problema, claro, y éste era que el autogobierno del pueblo estaba restringido, pues las autoridades judiciales de Calahorra -concretamente su Alcalde Mayor- tenían derecho a intervenir en Aldeanueva visitando o inspeccionando el trabajo de sus alcaldes y regidores y sus acuerdos y sentencias podían ser revocados por las autoridades de la ciudad ${ }^{10}$.

8. La magnitud de este fenómeno fue muy intensa, Helen Nader calculó que hacia 1500 un $60 \%$ de las poblaciones eran aldeas sometidas jurisdiccionalmente a villas y ciudades, mientras que en 1700 las tres cuartas partes de esos núcleos se habían convertido ya en villas. Cfr. Nader, H., Liberty in Absolutist Spain. The Habsburg Sale of Towns, 1516-1700, Baltimore, 1990, pp. 1-4.

9. Cit. en Sánchez Belén, J. A., La política fiscal durante el reinado de Carlos II, Madrid, Siglo XXI, p. 313.

10. Excepcionalmente, eso sí, se producían abusos en toda regla, como las requisas de trigo que ejecutaron las autoridades de Calahorra a los vecinos de Aldeanueva en 1583 y en 1606, acusándoles de especular con el precio del trigo para aprovecharse del hambre que había en la ciudad. Vid. A.H.N., Consejos, legajo 33.112. 
Para la mayoría de los vecinos ésta era, sin embargo, una situación soportable, y desde luego mucho mejor que lo que previsiblemente sucedería si se convertían en una villa con jurisdicción propia: en ese caso, habría que repartir los comunales de Calahorra y todas las experiencias previas indicaban que saldrían perdiendo. Pero había otro riesgo, éste menos explícito, pero mucho más grave: la existencia de un grupo de familias cuyo bienestar no dependía de los comunales y que aspiraba a mucho más que a ser regidores o alcaldes sometidos a la autoridad de Calahorra y a la de los concejos abiertos: eran los Ruiz de Bucesta y sus allegados, los Marín y los Zugasti ${ }^{11}$. Los Ruiz de Bucesta eran quienes realmente dirigían al grupo desde la sombra, hidalgos de solar conocido, como se decía entonces - procedían del Solar de Valdeosera ${ }^{12}$-, habían sabido no sólo buscar influencias políticas, sino también conseguir ingresos más allá de las actividades agrarias, pues desde hacía tiempo se dedicaban al comercio y a la industria y, según los vecinos, también al contrabando:

Todos ellos son comerciantes y tratantes en todos géneros y especies, y por estar esta villa un cuarto de legua del río Ebro, que divide el Reino de Castilla y de Navarra, tienen en él un molino harinero donde continuamente tienen un barco y de ordinario dos, y sin dependencia de los puertos podían comunicar sus comercios a reinos extraños en perjuicio de los derechos reales y contraviniendo las leyes y premáticas que prohíben la transgresión de todas las cosas vedadas ${ }^{13}$

El resultado fue que acumularon un poder y una riqueza muy superior al de cualquiera de sus convecinos ${ }^{14}$ y ello terminó por quebrar el equilibrio de la convivencia interna de la comunidad, pues, según sus enemigos, no se confor-

11. Los hermanos Zugasti, Domingo, Martín, Juan y Pedro, debieron llegar a Aldeanueva, procedentes de Arnedillo, a mediados del siglo XVI, se declararon hidalgos, pero los hombres buenos no les reconocieron tal condición, por lo que tuvieron que pleitear en la Sala de Hijosdalgo de la Chancillería de Valladolid, donde por fin consiguieron su propósito en 1557. Cfr. Archivo de la Chancillería de Valladolid, Sala de Hijosdalgo, Caja 309.3.

12. Para conocer los linajes hidalgos de Aldeanueva, véase Ruiz de Bucesta, Manuel Luis, "Aldeanueva de Ebro. Armas vivas. Armas perdidas", en Boletín A.R.G.H., no. 2 (Mayo), 2010, pp. 6-17 y "Heráldica en Aldeanueva de Ebro", Boletín A.R.G.H., no. 3 (Mayo), 2011, pp. 31-45

13. A.H.N., Consejos, leg. 33.987.

14. Celedón Ruiz de Bucesta es tratado por sus enemigos como un gran hacendado, sin embargo estaba lejos de ser un auténtico terrateniente. En 1666 constituyó un mayorazgo para su hijo con el tercio de libre disposición de su fortuna, constituido por 2 casas, 1 bodega, 376 olivos, 74 fanegas de huerta y sembradura y unas 9 fanegas de viña. Si tenemos en cuenta que sólo era el $30 \%$ de su fortuna, para los parámetros riojanos -con una propiedad de la tierra muy repartida- era un hombre rico, pero a una escala más global no pasaba de ser lo que se llamaba en la época un "dueño de mediana hacienda". Seguramente sus ingresos procedían en mucha mayor medida de las otras actividades comerciales e industriales a las que se dedicaba. Cfr. Archivo Familiar de Manuel Ruiz de Bucesta. 
maban con la riqueza, querían también el poder, y un poder que tenía que ser absoluto:

Juan Marín, mayor y menor, Celedón Ruiz de Bucesta y Ventura de Zugasti son personas poderosas y hacendosas y que con sus tratos y comercios tienen haciendas muy considerables y tan grandes que en todo el distrito de este corregimiento no hay otras personas que se les igualen ni lleguen con mucha cantidad a su caudal, y demás de lo sobredicho, no quisieran reconocer superior en la administración de justicia y antes bien, con la mano y poder que han tenido en la ciudad de Calahorra y en la villa, han estorbado el castigo de delitos gravísimos, sin dar lugar a que los alcaldes mayores obrasen conforme a derecho. ${ }^{15}$

Para estas familias, convencidas de poseer un status superior por el hecho de ser ricos e hidalgos, ejercer el poder en régimen de monopolio era algo, por así decirlo, natural, consustancial a su linaje y a su rango socio-económico, de modo que no dejarán nunca de intentar eliminar unas tradiciones de autogobierno que eran incompatibles con sus pretensiones. En 1635 ejecutaron el primer intento serio: La Corona, siempre necesitada de dinero, puso a la venta 10 regimientos en Aldeanueva -hasta entonces sólo habían existido 2 y con carácter electivo, uno ejercido por los hidalgos y otro por los pecheros-. Las familias más adineradas del pueblo se apresuraron a comprar los oficios ${ }^{16}$, que se vendían perpetuos y con juro de heredad, es decir, que los compradores iban a ser regidores de por vida y los oficios podían ser heredados por sus descendientes. Los vecinos tardaron en reaccionar, pero por fin en 1640 denunciaron al rey la situación que se había creado en el pueblo:

de la creación de los dichos 10 regimientos se sigue mucho daño y perjuicio por ser el lugar muy pequeño, que sólo tiene hasta 350 vecinos, los cuales están muy supeditados de los regidores y se comen con sus ganados los pastos, panes, viñas y heredades, de manera que no pueden vivir los demás vecinos ${ }^{17}$

Solicitaron y consiguieron del rey permiso para consumir los regimientos perpetuos, esto es, para suprimirlos indemnizando a sus compradores y pagando al rey otros 2.000 ducados adicionales por la autorización, de tal modo que el sistema tradicional de autogobierno pudo de momento subsistir.

15. A.H.N., Consejos, leg. 33.987.

16. Los compradores fueron Martín Marín, Diego de Ortuvia, Diego de Ocón, Juan de Ocón, Diego Marcilla, Celedón Ruiz de Bucesta, Juan de la Cuesta, Blas Pérez, Mateo Moreno y Diego Navarro.

17. Catastro de Ensenada. Copias de títulos y privilegios, AHPLR, Caja 31, vol. 32. 
Pero este grupo de familias no desistió, limitándose a buscar una nueva estrategia. La encontraron en la segregación de Calahorra, puesto que ello implicaba normalmente que el rey estableciese un nuevo régimen municipal que acabaría con los concejos abiertos, implantando el sistema ordinario en Castilla, el ayuntamiento o concejo cerrado. Así que desde mediados de siglo iniciaron toda clase de maniobras para conseguir que Aldeanueva se segregase, Ilegando a prometer que ellos pondrían el dinero que había que pagar al rey, de su bolsillo si hacía falta. Primero intentaron convencer con argumentos a los vecinos, pero sin ningún resultado. Tras el motín, sus enemigos lo explicaban así en el Consejo de Castilla:

Los vecinos siempre, por la conservación de los aprovechamientos comunales y no mover litigios ni controversias con la ciudad de Calahorra, han estado unidos a ella, sin haber hecho estimación de las molestias continuas que les han dado Juan Marín, mayor y menor, Celedón Ruiz de Bucesta y Ventura de Zugasti para que se eximiesen de la dicha jurisdicción de Calahorra, ofreciéndoles el dinero pertinente y necesario para la dicha exención. ${ }^{18}$

Tras este fracaso buscaron otras vías que, a la postre, desatarían los sucesos de 1663, estrategias en las que los objetivos políticos y los familiares se entrelazaron $^{19}$. Celedón Ruiz de Bucesta se había casado con una muchacha de Rincón de Soto, María de Arnedo ${ }^{20}$, emparentada con el oidor de los Consejos de Castilla y de Hacienda Martín Íñiguez de Arnedo, Caballero de Santiago ${ }^{21}$, quien decía descender, por parte de madre "de los atenienses romanos y de Juan Domínguez de Arnedo, uno de los conquistadores de Sevilla" y por parte de padre "de los reyes de Navarra y del rey godo Eurico"22. Don Martín, originario de El Villar de Arnedo, era un hombre poderoso y bien informado en la Corte, y probablemente fue él quien preparó la estrategia a emplear. Recurrió a aquel viejo acuerdo que citábamos de las Cortes de $1639^{23}$ y a su hijo Juan Manuel,

18. A.H.N., Consejos, leg. 33.987.

19. Los Marín, los Bucesta y los Zugasti no sólo compartían objetivos políticos, sino que estaban emparentados entre sí, Juana Antonia Ruiz de Bucesta y Arnedo, hija de Celedón Ruiz de Bucesta, se casó el 7 de enero de 1666, con Miguel Marín y Zugasti, hijo de Juan Marín, Cfr., Manuel Ruiz de Bucesta, "Heráldica..., art. cit., p. 38.

20. Véase el testamento de Celedón Ruiz de Bucesta, 30-8-1664.

21. Véase su expediente en A.H.N., Órdenes Militares, Santiago, Exp. 4099.

22. Cfr. Francisco Mariano Nifo, Cajón de sastre o Montón de muchas cosas buenas, mejores y medianas, Madrid, 1761, Tomo VII, p. 95.

23. En 1662, cuando se pone en marcha toda la estrategia para vender el pueblo, la situación de la Hacienda Real era especialmente crítica, pues el Estado se había declarado en bancarrota ese mismo año. Además, estaba en marcha la que se esperaba fuese la campaña definitiva para reincorporar Portugal a España, con un ejército de 20.000 hombres actuando en tierras portuguesas que consumía más de 6 millones de ducados al año (las bancarrotas de 
que llegaría a ser, durante unos meses, señor de Aldeanueva de Ebro. Juan Manuel era, a la sazón, catedrático de Decretales en la Universidad de Salamanca, había nacido en Granada, donde su padre estaba por entonces destinado, y en 1656 fue admitido en el aristocrático Colegio Mayor de San Bartolomé de Salamanca, dos años después se licenció en Leyes y recibió el hábito de Caballero de Santiago ${ }^{24}$ y para 1660 era ya Rector de la Universidad ${ }^{25}$. Semejante carrera, obviamente, no hubiese sido posible sin la ayuda de su poderoso padre, que precisamente pensó en él para que su familia diese un paso adelante en su ascenso social: hacerse señores de vasallos, la antesala para acceder a la nobleza titulada ${ }^{26}$. Para los Bucesta y sus allegados era un plan perfecto: si el Señor de la villa terminaba siendo su pariente, no cabía duda alguna sobre quién iba a ejercer el poder efectivo en ella.

Un primero de abril de 1663, sin que los vecinos de Aldeanueva tuviesen noticia alguna, se firmaba un sigiloso acuerdo de venta de la jurisdicción de la aldea por un valor de 4,125.000 maravedís de plata, a razón de 15.000 por vecino o familia (tenía 275). La nueva villa cambiaría su nombre por el de "Arnedo de Ebro", en honor de don Juan Manuel Íñiguez de Arnedo, pero que era también -para desesperación de los vecinos- el apellido del hijo de Celedón Ruiz de Bucesta, que se llamaba Carlos Ruiz de Bucesta y Arnedo. Los trámites se siguieron con inusitada rapidez y el rey ratificaba el contrato de venta unos días después, el 12 de abril. En previsión de que hubiese problemas, los Ruiz de Bucesta y sus parciales habían tomado la prudente decisión de trasladar su residencia a Alfaro, y no era una decisión caprichosa. En la cultura popular de la época, ser vasallos de un señor particular -como decían los vecinos de Aldeanueva- era una humillación colectiva intolerable ${ }^{27}$, independientemente de los perjuicios o beneficios materiales que ello implicase, de modo que era difícil prever cuál iba a ser la respuesta de los vecinos del pueblo cuando se enterasen y mucho menos qué podían esperar quienes, a juicio de la población, serían

la Hacienda Real habían sido constantes desde Felipe II, produciéndose en 1557, 1575, 1596, 1607, 1627, 1647 y 1652). Vid., Domínguez Ortiz, A., Política y hacienda de Felipe IV, Madrid, 1960; Pulido, Ildefonso, La Real Hacienda de Felipe III, Huelva, 1995; y Carlos Morales, Carlos Javier de, Felipe II: el imperio en bancarrota. La Hacienda real de Castilla y los negocios financieros del Rey prudente, Madrid, 2008.

24. Véase su expediente en A.H.N., Órdenes Militares, Santiago, Exp. 4.098.

25. Se conserva el inventario de su biblioteca personal, fechado en 1668, formada casi exclusivamente por libros de derecho, en el Archivo Histórico Provincial de Salamanca, leg. 3.016, f. 824.

26. José Rojas y Contreras, Historia del Colegio Viejo de S. Bartolomé Mayor de la célebre Universidad de Salamanca: Que contiene las Vidas de los cinco Eminentísimos y las entradas de los que desde el año de 1640 hasta el de 1768 han sido elegidos en el Mayor de San Bartolomé, Volumen 2, p. 426.

27. Véase Carzolio, M. I., "En los orígenes de la ciudadanía en Castilla: la identidad política del vecino durante los siglos XVI y XVII", en Hispania, vol. 62, n² 211, 2002, pp. 637-691. 
una cuadrilla de traidores que habían vendido el pueblo a un particular para poder controlarlo todavía con mayor impunidad que hasta entonces.

El 6 de mayo, un Receptor del Consejo de Hacienda se presentó en el pueblo a las 8 de la mañana, una hora a la que todos los vecinos estaban trabajando en el campo, y notificó a las autoridades presentes, a la sazón Miguel Ruiz de Bucesta, alcalde ordinario del estamento hidalgo, la decisión del rey de otorgar el señorío sobre Aldeanueva a don José Manuel Íñiguez de Arnedo. El alcalde, como cabía esperar, no apeló la decisión (cosa que sin duda hubiese hecho el alcalde de los hombres buenos, Martín Roldán, que se convertiría luego en el líder de los tumultos). Al no haber ninguna contradicción, se otorgó la posesión a don Juan Manuel Íñiguez de Arnedo (que no estaba presente) y se procedió a nombrar como Alcalde Mayor a Antonio de Bilbao, un paniaguado de los Ruiz de Bucesta, según denunciarían más tarde los vecinos.

La noticia corrió como la pólvora y las campanas de la parroquia Ilamaron a concejo abierto. No todos acudieron a la asamblea, por supuesto, quienes habían tramado la operación seguían los acontecimientos, prudentemente, desde Alfaro. La legislación vigente permitía a las aldeas vendidas tantear su jurisdicción, es decir, pagar al rey la misma cantidad en que se hubiese cerrado la operación y ser a partir de entonces una villa, pero de realengo ${ }^{28}$. La asamblea decidió tratar de impedir a toda costa la venta, lo cual exigía disponer de unos recursos económicos muy elevados, pero todo era poco para evitar la perspectiva de depender de un señorío y verse sometidos al poder los Bucesta y sus amigos, como explicaban en el documento que se aprobó por votación:

No lo pueden excusar respecto de ser la dicha venta y vasallaje tan gravoso, como lo tienen experimentado en los vecinos que son de los lugares de señorío y en el estado eclesiástico de los dichos lugares, pues todos están notablemente lesos en parte muy considerable de intereses y exenciones y porque los dichos daños tienen su origen en las cargas, gravámenes y vejaciones con que los señores molestan a los dichos vecinos, como a sus vasallos, muy de continuo y reconociendo no habían de poder tolerar las sinrazones y ofensas de los dichos Don Juan Marin y don Celedonio Ruiz de Bucesta, ansí por la mano de poderosos como por la que les había de dar el dicho Don Juan Manuel, por ser sus deudos y haberse movido a la compra del dicho señorío a su instancia y persuasiva

28. Para contrarrestar el enorme malestar social que provocaba en las poblaciones de realengo el ser señorializadas, una Real Cédula de 1626 permitió a aldeas comprar su propio señorío, es decir, hacerse "señores de si mismos" y otra de 1632 permitió tantear la jurisdicción al comprador, permaneciendo entonces como municipios de realengo (esta fue la opción que trató de usar Aldeanueva). Vid. Marcos Martín, A., "Hipotecar la hacienda común. Enajenaciones del patrimonio regio y endeudamiento municipal en los siglos XVI y XVII", en Historia de la Propiedad. Crédito y garantía. Madrid, 2007, pp. 186-187. 
El pago se hacía en varias entregas, pero hacía falta de inmediato, en un plazo de 60 días, reunir 1,500.000 maravedís de plata, una auténtica fortuna: 4.000 ducados de plata equivalían al sueldo de muchos años de un trabajador bien pagado de la época. Los Bucesta y sus aliados, por supuesto, no se comprometieron a contribuir a la operación, pero es que su comportamiento en las semanas siguientes fue, según los vecinos, una serie de maniobras para tratar de impedir que los vecinos reuniesen el dinero por su cuenta, su objetivo, según relataron al Consejo de Hacienda, era el mismo que siempre habían perseguido:

y habiéndose unido todos los vecinos para el dicho tanteo y dado poder competente para él ... con sus personas y bienes... para que se tomasen a censo cuatro mil ducados de plata ... y quedar exentos del dicho señorío y vasallaje, sin faltar ninguno... excepto los dichos Don Juan Marin y Don Celedonio Ruiz de Bucesta que se sustrajeron de asistir a los dichos poderes y dar su consentimiento para el dicho tanteo... y no contentándose con no ayudar... se han opuesto a ella y han desamparado la villa y la unión de su vecindad y... están haciendo todas las diligencias posibles por si y por sus amigos para que el dicho concejo y vecinos no hallen quien les de el dicho dinero a censo, poniendo sus caudales en mala voz para que por este camino dar tiempo y lugar a que se pase el termino del tanteo y quedar los suso dichos dueños de la villa y sus vecinos ${ }^{29}$

Los diputados elegidos por los vecinos acudieron en primer lugar al Convento de San Bernardo de Fitero, donde, inicialmente, recibieron garantías de que se les prestarían los 4.000 ducados que necesitaban de inmediato, pero las maniobras de los Bucesta y compañía frustraron la operación, otro tanto sucedería en Logroño:

habiéndose hallado los dichos cuatro mil ducados en el Convento de San Bernardo de la villa de Fitero y estándose para hacer la entrega la han estorbado y no se ha podido conseguir su recibo y teniendo el dicho dinero ansimismo dispuesto en la ciudad de Logroño, habiendo ido a otorgar el censo de él Zeledón Gutiérrez... por medio de Don Antonio Beltrán, su deudo y amigo, han dispuesto el que le prendiesen en la dicha ciudad de Logroño, con cuyas extorsiones ponen impedimento injusto al dicho concejo y vecinos para hallar dinero y hacer el dicho tanteo.

29. Archivo Municipal de Aldeanueva, Caja 1.6. Doc. proporcionado por Javier Vicuña y editado íntegro por Vicuña Ruiz, Francisco Javier, "El Motín de Aldeanueva" en Berceo, $\mathrm{n}^{\mathrm{o}} 102,1982$, pp. $71-102$. 
El tiempo iba pasando inexorablemente y el plazo de 60 días, que cumplía a mediados de junio, se acercaba. Todo eran rumores y discusiones cuando un 23 de mayo se presentó secretamente en el pueblo Juan Vela, Receptor del Consejo de Hacienda, para otorgar definitivamente la posesión del señorío a don Juan Manuel Íñiguez de Arnedo tras amojonar su término jurisdiccional e instalar la picota u horca, el símbolo del poder señorial. Todo era muy anómalo, pues el plazo de 60 días de que disponían los vecinos para reunir los 4.000 ducados no había concluido -faltaban tres semanas-, pero todo estaba previsto para aplicar la política de los hechos consumados. El Receptor llegó arropado por el Alcalde Mayor que había designado el nuevo señor y sus alguaciles. No se llamó por el modo tradicional a concejo abierto, sino que se preparó un simulacro de asamblea vecinal formada por los partidarios de los Bucesta:

Hicieron se diera la posesión del dicho señorío y vasallaje sin llamar a concejo abierto en la forma que se acostumbra, por voz de pregonero y campana tañida y muñiendo por la tarde, asistiendo a él hasta veinticinco o veintiséis personas, sus aliados, que con prevención los tenían para que, entrando el dicho Juan Vela, como entró a ocho y nueve de la mañana y a hora que los vecinos están en la granjería de sus campos, diese la posesión cautelosa y atropelladamente

Fueron días agotadores para el Receptor del Consejo y sus auxiliares, de trámites administrativos, recorriendo todo el futuro término municipal para instalar lo mojones que habrían de delimitarlo, notificando a todas las poblaciones comarcanas la nueva situación jurisdiccional del pueblo y resolviendo las alegaciones que se presentaban, y todo este trabajo en un ambiente de hostilidad apenas disimulado... pero lo peor estaba por llegar.

Habían pasado ya tres días desde la llegada del Receptor y, salvo un breve incidente con un regidor opuesto a los Bucesta, Bartolomé Falcón, que terminó encarcelado por el Alcalde Mayor, todo parecía estar bajo control. Era un 26 de mayo y llegaba un momento cargado de simbolismo, instalar la horca o picota, símbolo de la nueva condición de villa del pueblo y, en este caso, también del poder del señor sobre sus vecinos. Dado el ambiente de tensión que se respiraba en el pueblo, el acto se celebró con cierta discreción, pero sin que los vecinos hicieran acto de presencia ni tratasen de impedirlo. Ya por la tarde, con el trabajo terminado y el ambiente aparentemente en calma, el Receptor decidió dejar los documentos en la posada donde se hospedaba, relajarse y salir a charlar un rato con la media docena de vecinos que se prestaban a dirigirle la palabra, casi todos cargos públicos del estamento hidalgo vinculados con los Bucesta:

por la tarde, antes de anochecer, estando en la plaza de la dicha villa ... vi que salieron de la Iglesia Bartolomé Falcón y Diego González, regidores, y hasta diez y seis o doce, y por estar preso el dicho Bartolomé 
Falcón, regidor, por orden del Alcalde Mayor, en las casas de Ayuntamiento de la villa, me causo novedad ${ }^{30}$

De haber sabido lo que había ocurrido mientras él trabajaba en su despacho, hubiese huido de inmediato, pero no lo sabía. El regidor Bartolomé Falcón había escapado de su reclusión y se había reunido en la Iglesia, en secreto, con un reducido grupo de vecinos, entre ellos el alcalde ordinario de los hombres buenos, Martín Roldán, y, probablemente, el cura Martín Suberto, que había estado en todo momento, desde un segundo plano, implicado en la resistencia vecinal contra los Bucesta. Allí debieron planificarlo todo, porque nada más salir de la Iglesia, un tropel de gente, que previamente había sido convocada para ello, se unió al pequeño grupo de conjurados, el Receptor fue testigo de todo:

Se fue juntando hasta donde estaban los dichos regidores y la demás gente otras muchas personas y comenzaron a decir "¡Viva el rey y muera el mal gobierno! y otras muchas palabras muy feas, diciendo "iMueran! ¿Quién lo ha hecho? Fuenteovejuna

La situación se tornaba peligrosa y el Receptor, asombrosamente celoso de su oficio, pensó en salvar los documentos oficiales que había dejado en la posada -O eso dijo después-, pues le informaron que los vecinos tenían pensado arrebatárselos. Sin embargo, los hechos se desencadenaron con demasiada rapidez como para que pudiese siquiera intentarlo... sólo le quedó una salida, correr:

El tumulto de gente estaba dando grandes voces y unos echaron por la parte donde estaba el Alcalde Mayor y otros contra mí, y empezaron a decir "¡Mueran, mueran!", con lo cual nos desapartamos, yo eché a correr para salvar la vida y cada uno de los que iban conmigo por su parte, hasta que en una calle que se va al campo, cayéndome, me quitaron espada, capa y sombrero y hicieron muchos malos tratamientos

La violencia, contra lo que pueda parecer, estaba perfectamente planificada y, llegado el caso, contenida. Se trataba de hacer una demostración de fuerza intimidatoria, no de asesinar a nadie-podrían haberlo hecho, de haber querido, con toda facilidad-. Le arrebatan la capa, el sombrero y la espada porque eran los signos de distinción de un caballero de la época, y quitárselos era una forma ritualizada de humillarle públicamente, pero luego le dejan huir, y si alguien pierde los nervios, inmediatamente se le impide pasar a mayores, como de hecho sucedió:

Y uno de ellos, que he oído decir se llama Manuel Gutiérrez, alzó una azada y, teniéndola levantada para matarme, se agarró una mujer con él y le detuvo

30. A.H.N., Consejos, leg. 33.987. 
El bueno del Receptor, magullado, humillado y aterrorizado, fue recogido por un vecino, que le escondió en su casa, pero poco después la multitud rodeó el edificio con la misma intención amenazante:

Y después desto, mucho tumulto de gente llegó diciendo que me entregase a ellos, que abriese la puerta, y porque no lo quiso hacer, comenzaron a tirar muchas pedradas y a decir muchas palabras feas.

El Receptor terminó huyendo por una ventana del desván, saltando de tejado en tejado hasta que pudo esconderse dentro de una bodega, donde pasaría la noche aterrorizado, oyendo como partidas de vecinos andaban buscándole por el pueblo. Ya al amanecer, cuando las calles quedaron momentáneamente en calma, huyó corriendo campo a través hacia Calahorra, donde encontró refugio. Parecidas peripecias sufrieron sus colaboradores y los vecinos que le habían ayudado de algún modo. Los amotinados eran ahora los dueños del pueblo.

El Alcalde Mayor de Calahorra, que le acogió en su casa, le puso en antecedentes sobre lo que había ocurrido aquella noche en Aldeanueva mientras él dormitaba escondido en la bodega:

Habían ido y traído la horca a la plaza y la habían quemado en ella, y don Pedro Trápaga Alvarado, Alcalde Mayor, estaba en casa de Ventura Zugasti, porque a pedradas le habían metido dentro, y que también habían querido quemar la casa donde estaba el dicho Alcalde Mayor y la de Celedón Ruiz de Bucesta, Juan Marín y Juan de Miranda, y que habían hecho grandes fuegos a la puerta de los susodichos

Los vecinos, en realidad, no buscaban al Receptor para matarle, como él temió aquella noche, sino para quitarle toda la documentación, pues esperaban encontrar en ella las pruebas que demostraran las maniobras indebidas de los Bucesta. Por este mismo motivo registraron la posada, y el posadero, que se había convertido en sospechoso de simpatizar con los Bucesta por su continua relación con el Receptor, sufrió las consecuencias:

El tumulto de gente le había querido dar tormento a él y a Juan Francisco Pérez, organista, que si no les decían dónde estaban los papeles o quién los tenía, les habían de dar tormento en sus vergüenzas en el torno del cerrajero

Ante tal perspectiva, claro, confesó donde estaban, un lugar previsible por otro lado: en casa del suegro de Juan Marín, cuya casa fue asaltada de inmediato y los documentos requisados. El ritual habitual en este tipo de tumultos consistía en quemar los documentos señoriales en la misma pira en que ardía su horca, en un ritual simbólico de destrucción del poder señorial, pero ya hemos 
dicho que todo estaba planificado, de modo que el cura Martín Suberto exigió revisarlos antes y, una vez hecho esto, prohibió que se quemasen:

y por reconocer que entre ellos había unos traslados de Cartas Ejecutorias de la villa sobre pastos della no los habían quemado y que el dicho cura les había dicho que era preciso que se apartasen y para este efecto llevarlos a un letrado, con que evitó el quemar los papeles.

Mientras tanto, grupos de vecinos armados rodeaban la casa de Celedón Ruiz de Bucesta, la del Alcalde Mayor nombrado por el señor y las de sus principales colaboradores y prendían hogueras ante sus puertas, las apedreaban, picaban los escudos nobiliarios de sus fachadas y hacían disparos de arcabuz al aire. Era, como hemos dicho, una violencia ritualizada y simbólica, que usualmente terminaba sin víctimas, pero por si acaso, los clérigos intervenían para contener los ánimos de los más exaltados, un testigo relató más tarde estos acontecimientos:

Este testigo se salió a la ventana y vio que en una hoguera que estaba ardiendo echaron unos palos grandes como vigas y decían que era la horca, que la habían quitado de donde estaba y haciendo desto mucha fiesta y grande ruido, y porque la hoguera estaba cerca de la puerta de Celedón Ruiz de Bucesta y viendo hacer esto estaban dos curas, que decían que por amor de Dios, no llegasen la lumbre a la puerta del dicho Celedón, que era lástima quemarle la casa. Y ansimismo oyó este testigo decir que otros dos sacerdotes estaban a las puertas de Ventura de Zugasti, pidiendo a la gente del tumulto que tampoco le quemasen la casa, pues con hacerlo no se remediaba nada. Y que otros dos clérigos estaban a la puerta de Juan Marín, familiar, haciendo la misma diligencia

Al final de la noche, después de semejante despliegue de amenazas, sólo se pudo encontrar un herido de cierta consideración: el Alguacil Mayor designado por el Señor, Juan de Miranda, que había recibido una pedrada.

Con todo, los vecinos habían cometido unos delitos gravísimos, aunque no hubiese corrido la sangre, como el de formar ligas y monipodios, es decir, conjurarse para realizar actividades subversivas, y el de resistencia a la justicia, al atacar al Receptor del Consejo de Hacienda y al Alcalde Mayor del Señor -entre otros-, ambos tipificados, por su especial gravedad, como casos de Corte, esto es, cuyo conocimiento competía en exclusiva al rey, y castigados incluso con pena de muerte. Así que cuando, el 14 de junio, llegó a la villa el juez pesquisidor nombrado por el Consejo de Castilla, don Juan Ruiz Fernández, Abogado de los Reales Consejos y Alcalde Mayor de Alfaro, seguro que fueron muchos los que dejaron de dormir tranquilos. Sin embargo, el Consejo de Castilla solía actuar con enorme cautela en estos casos, sabedor de que tomar decisiones precipitadas o demasiado rigurosas contra toda una comunidad decidida y organizada podía ser peligroso. De este modo, la prioridad del Consejo no era tanto 
condenar con rigor a los implicados como devolver la paz social a la villa... y para eso era imprescindible que ninguno de los dos bandos se considerase ni totalmente vencedor, ni totalmente vencido.

El pesquisidor hizo público un bando por el que invitaba a declarar voluntariamente a todos los que hubiesen sido testigos de los hechos y notificó a las autoridades locales que, mientras durase la investigación, él era, por orden del rey, la única autoridad jurisdiccional en el pueblo. La actitud de la población fue desalentadora: los únicos testigos que se prestaron a declarar fueron los oficiales del Receptor y el Alcalde Mayor señorial, con cuyos testimonios el juez pudo dictar 13 autos de prisión e iniciar los interrogatorios de los que habían sido reconocidos por tan exiguos testigos. Pero, para desesperación de las víctimas del motín, el ambiente distaba mucho de ser el de una campaña represiva, como se quejaba el Alcalde Mayor señorial:

Todos los procesados no vienen a tener de presos más que el nombre, porque en lo demás se andan con total y absoluta libertad y estándose en sus casas, acudiendo a sus haciendas y paseándose por las calles, muchos de ellos con armas y haciendo corros en la plaza... y lo peor es que andan amedrentando los vecinos para que no digan la verdad, y se agavillan de noche, que andan tirando arcabuzazos y haciendo otros excesos

En realidad, los amotinados apenas tuvieron que amedrentar a un puñado de testigos, entre otras cosas porque la gran mayoría de los vecinos habían participado de un modo u otro en el motín. Lo que sí se produjo -y probablemente mediando asesoramiento profesional- fue una planificación perfecta de lo que cada uno tenía que declarar ante el juez, para impedir que éste obtuviese pruebas de cargo sólidas contra ninguno de los implicados y, según parece, todo ello organizado por varios curas de la parroquia, como se quejaba el todavía Señor de Aldeanueva, José Manuel Íñiguez de Arnedo:

Los acusados y muchos de los testigos que han depuesto han Ilevado por máxima el dar a entender que en el motín y sedición fueron culpados todos o casi todos los vecinos desta villa, y así lo declaran dando memoria dellos por mayor, comprendiendo también hasta las mujeres y los muchachos... Es causa pública de todos el título amable de libertad y esperanza del tanteo y así están todos tan unos, tan conformes y confederados que ninguno tendrá voluntad de decir cosa que sepa. Mayormente que es cierto el haber andado personas eclesiásticas hablando a los vecinos, así hombres como mujeres, imponiéndolos en lo que tenían que decir, caso que Vuestra Merced los examinase, y otros han andado amenazándolos, y con uno y otro medio los han puesto tan uniformes como Vuestra Merced ha podido reconocer, pues confesando muchos o casi todos el motín y sedición y demás delitos consiguientes, en llegando 
a la declaración formal de los cómplices dicen que fue todo el lugar o que fueron tantos que no los pueden comprehender, y ésta es malicia conocida.

El Alcalde llegó a exigir que el Pesquisidor torturase a los testigos para conseguir confesiones útiles, aunque, afortunadamente, nadie llegó a ser colocado en el potro. Las quejas del Alcalde no eran invenciones, los testigos llevaban perfectamente memorizada hasta la última palabra de lo que tenían que responder cuando el juez les preguntase por los participantes en el motín; sus declaraciones, que se conservan en el Archivo Histórico Nacional, son todas idénticas:

Era todo el lugar menos Juan Marín, Celedón Ruiz y Ventura Zugasti, e asistían mujeres y muchachos, que fueron tantos que no les puede contar por menor

En realidad, la estrategia estaba ya perfectamente planificada desde antes de que se produjesen los hechos, no en vano los primeros gritos que oyó el Receptor fueron aquellos versos que había popularizado muchos años antes Lope de Vega ${ }^{31}$ : ¿Quién lo ha hecho? Fuenteovejuna". Obviamente, los Bucesta tenían partidarios en Aldeanueva, pero ninguno de ellos se atrevió a declarar porque eran una pequeña minoría... y además, tenían que seguir viviendo en el pueblo cuando el pesquisidor se hubiese ido. Hubo, con todo, algún caso de vecinos que no siguieron al pie la letra las consignas, y contra ellos se actuó sin contemplaciones, recurriéndose, ahora si, a las amenazas. Fue el caso, por ejemplo, del mesonero, del organista de la parroquia y del oficial del Receptor, tres de los pocos testigos que habían incluido nombres de personas en su declaración ante el juez, y cuyas casas fueron apedreadas durante varias horas la noche el 11 de agosto, con el Pesquisidor todavía presente en la villa, pues para los amotinados no eran sino traidores.

Los vecinos desplegaron una amplia batería de argumentos con los que justificar su comportamiento. En primer lugar, por supuesto, toda la trama que habían organizado los Bucesta para ejecutar la venta de la jurisdicción del pueblo y para impedir que consiguieran el dinero necesario con el que impedirla y el conjunto de anomalías de procedimiento que se habían producido desde la Ilegada del Receptor. Pero había otros argumentos mucho más interesantes. El primero era la libertad, que ellos asociaban al hecho de continuar siendo vasallos del rey y no de un señor particular:

reconociendo los vecinos que por emulación y sujeción lo habían sacado del patrocinio directo de su rey y señor natural y los habían querido poner en segundo vasallaje, siendo este tan odioso y perjudicial a la

31. Fuenteovejuna, de Lope de Vega, se publicó por primera vez en Madrid en 1618. 
buena administración de justicia, como se ve y experimenta en todos los lugares de señorío, hicieron la dicha aclamación o tumulto apellidando su libertad, sin que se dijese a otro fin y efecto más de publicar su ánimo y deseo a voces para que todos los tuviesen entendido.

En segundo lugar, ya lo señalábamos antes, que la situación política y económica de Aldeanueva no era de absoluto sometimiento a Calahorra, de tal manera que la segregación podía resultar perjudicial económicamente para los vecinos, luego el motín se convertía así en un acto legítimo de defensa del bien común frente a los intereses particulares de los partidarios del Señor ${ }^{32}$ :

Los vecinos, estando en el vasallaje de Su Majestad y unidos y avecindados a la jurisdicción de Calahorra, gozaban sin controversia de los pastos de sus términos uniformemente con ella, en comunidad, y traían las aguas para el riego de sus heredades y coseras en la misma uniformidad, sin que en estos aprovechamientos hubiese afectación de personas entre los habitantes de esta villa y los de la ciudad de Calahorra, de cuyo aprovechamiento y gozo no han sabido después de la dicha posesión, por estárseles prohibiendo con prendaduras y aprendimiento de ganados o restringiéndolos a las coseras tan limitadas que les fueron amojonadas al tiempo de la posesión, en las cuales no es posible alimentarse el ganado de trabajo y menos el mayor, vacuno y lanío.

Como ya indicábamos, tras la apariencia de un tumulto espontáneo y violento se escondía una cuidadosa planificación, ejecutada después con absoluta disciplina por los amotinados. Leyendo sus alegaciones comprendemos mejor el por qué de la limitación del uso de la violencia, que había quedado restringida a una especie de ritual simbólico:

En el dicho tumulto no hubo ni calentamiento de casa, herida ni homicidio, ni otro delito igual y equivalente a lo referido, como parece de la sumaria, y aunque dicen los testigos hubo hogueras, todos califican se hicieron en la plaza y en medio de las calles, lo cual no se puede llamar incendio propiamente para que le corresponda la pena de la ley.

32. En realidad, las mentiras o las verdades a medias son lo habitual en estos alegatos. En este asunto, por ejemplo, aunque es cierto que el término jurisdiccional de Aldeanueva no incluía los viejos comunales de Calahorra, también lo es que la Corona decretó que sus vecinos podrían seguir usándolos pese a la segregación jurisdiccional. Lo que sí solía ocurrir era que los guardas de los comunales tuviesen un trato discriminatorio con los vecinos de las aldeas segregadas. Véase para el caso de Aldeanueva AHPLo., Legajo 6.370, 1665, Folios 77-78, AHPLo., Legajo 6.369, 1666, Folio 90 y AHPLo., Legajo 6.370, 1665, Folios 85-86 Documentos cedidos por $\mathrm{D}^{\mathrm{a}}$ Sara Bustos. 
Otro riesgo era que les aplicasen las leyes contra ligas y monipodios, es decir, de haberse conjurado para organizar el motín, o incluso las que castigaban el delito de sedición, de rebelión contra el rey, pues las penas eran rigurosísimas, incluyendo el servicio en galeras y la horca para los culpables. Los amotinados no sólo habían anunciado desde el primer momento su fidelidad a la Corona gritando "¡Viva el rey y muera el mal gobierno!", sino que sus alegaciones tratarán de argumentar -cosa incierta- que fue una explosión de ira incontenible y espontánea, fruto de la indignación por los atropellos que estaba sufriendo el pueblo:

El justo sentimiento de los vecinos por la causas y razones que quedan alegadas les eximió de cualquiera culpa o delito, especialmente no habiendo sido deliberado, sino accidental e inopinado, y porque se reconoce lo sobredicho de los efectos, pues se hallaron los vecinos sin armas, indicio que califica en parte el ánimo interior antecedente a delinquir, y por haber sido después de la Salve y en hora que, de haber sido tratado y comunicado el tumulto, pudieran haber muerto las personas que fueran de su voluntad... Y si hubiera habido intención y voluntad de delinquir, ésta había de dirigirse contra los dichos Juan Marín, mayor y menor, Celedón Ruiz y Ventura Zugasti... Y porque no fue premeditado y acordado el tumulto antecedente no es fácil el verse autores ni promovedores de él, ansí por lo dicho como por haber sido de noche y haber concurrido tanta gente de todo género, en cuya confusión es impusible el querer ajustar los promovedores.

Un riesgo especial de sufrir condenas severas lo tenían el alcalde ordinario de los hombres buenos, Martín Roldán, y los dos regidores, a quienes apuntaban todos los indicios como líderes del motín y, aunque esto no pudiera probarse, resultaba evidente que no habían ayudado en nada al Receptor del Consejo de Hacienda ni al Alcalde Mayor señorial y que tampoco habían intentado contener a la multitud. En este asunto los argumentos de los vecinos giraban en torno al concepto de prudencia -muy del gusto del Consejo de Castilla, por cierto- o, concretamente, a no querer enervar más todavía a los vecinos tratando de contenerlos:

Porque de no haber podido aquietar el tumulto por entonces no se infiere hubiera habido dolo por su parte, porque una concitación universal de un pueblo no es fácil resistirla la justicia, de lo que se ve y experimentan ejemplares cada día, y últimamente las autoridades en estos términos excusan a los ministros, aconsejan y dan por arbitrio que la mejor expedición y quietud del tumulto es condescender por entonces con lo que aclama la plebe, porque resistirla fuera exponerse evidentísimamente a la muerte. 
Don Juan Manuel Íñiguez de Arnedo se desesperaba ante semejantes argumentaciones, que ponían en duda que hubiese existido siquiera una sublevación antiseñorial -a la que, si se demostraba que había ocurrido, también había que aplicar las penas por sedición, esto es, la horca:

Si sus acciones no han sido en odio del señorío jurisdiccional de mi parte $i$ A dónde miran tantas razones como se alegan para desacreditar la jurisdicción de los señores particulares de vasallos? Llamándole odioso y perjudicial a la buena administración de justicia, y dando a lo contrario el dulce nombre de libertad, cuando esta villa no ha sabido gozar jamás sino de una penosa esclavitud y servidumbre debajo del yugo de la ciudad de Calahorra, tan pesado como es notorio.

En su alegato de conclusiones, el procurador del Señor exigía penas ejemplares para los procesados, argumentando que si no se hacía así y los delitos quedaban impunes, sería imposible en el futuro que los nobles y el propio rey controlasen a una población insumisa ${ }^{33}$ :

Cuando se cometen los delitos con tanta publicidad, notoriedad y escándalo y mal ejemplo, como en este caso, y siendo tan malas consecuencias, pues si estos excesos se quedasen sin castigo, sería dejar a mis partes con unos vasallos rebeldes, obstinados a desobediencia y desorden, y otras villas que vendiese Su Majestad tomarían ejemplo para sus desafueros... y no es bien que se sepa que pueden los vasallos, a título de muchos, tumultuar y oponerse a los decretos y disposiciones reales, y si no se castiga el exceso de una república, se aventura mucho en el ejemplar, pues fácilmente puede correr de un lugar a dos y a más y a una provincia y a un reino, y la principal potestad real consiste en la obediencia y respeto de los súbditos, porque roto el fuero de la sujeción, es fácil dejar la Majestad desarmada, y en los movimientos pequeños se ha de hacer escarmiento para los grandes.

La estrategia con la que se planificó el motín, la disciplina con que se ejecutó y la fortaleza de testigos y procesados para no decir ni una palabra más de lo debido ante el pesquisidor dieron sus frutos, de tal modo que el juez sólo fue capaz de procesar a 68 vecinos -una pequeña parte de los que habían participado en el motín-, y además a 19 de ellos los tuvo finalmente que absolver por falta de pruebas. El 19 de septiembre se leyeron en audiencia pública las sentencias contra los procesados:

33. No iba muy desencaminado el letrado, pues dos años después, en 1665, los vecinos de Calahorra se amotinaron también y expulsaron a los nobles de la ciudad. Vid., Lorenzo Cadarso, Pedro Luis, Los conflictos populares en Castilla en los siglo XVI y XVII, Madrid, Siglo XXI, 1996. 
TABLA 1.

\begin{tabular}{|c|c|c|c|c|c|}
\hline NOMBRE & Edad & OFICIO & COSTAS & $\begin{array}{c}\text { SENTENCIAS } 1^{\mathrm{a}} \\
\text { INSTANCIA (1663) }\end{array}$ & $\begin{array}{c}\text { SENTENCIAS EN } \\
\text { APELACIÓN (1679) }\end{array}$ \\
\hline Aguado, Juan & 25 & Labrador & 200 reales & $\begin{array}{l}4 \text { años de Presidio y } \\
4.000 \text { maravedís }\end{array}$ & 20.000 maravedís \\
\hline Castillo, José & 48 & Labrador & 50 reales & Absuelto & Absuelto \\
\hline Cuesta, Diego de la & 27 & Labrador & 60 reales & $\begin{array}{l}2 \text { años de destierro y } \\
4.000 \text { maravedís }\end{array}$ & 4.000 maravedís \\
\hline Díaz, Pedro & 33 & Labrador & 200 reales & $\begin{array}{l}4 \text { años de Presidio y } \\
4.000 \text { maravedís }\end{array}$ & $\begin{array}{l}4 \text { años en un Presidio } \\
\text { y } 20.000 \text { maravedís }\end{array}$ \\
\hline Falcón, Bartolomé & 34 & Regidor & 50 reales & Absuelto & $\begin{array}{l}4 \text { años en un Presidio } \\
\text { y } 20.000 \text { maravedís }\end{array}$ \\
\hline $\begin{array}{l}\text { Falcón, Francisco } \\
\text { Sebastián }\end{array}$ & 30 & Labrador & 200 reales & $\begin{array}{l}4 \text { años de Presidio y } \\
4.000 \text { maravedís }\end{array}$ & 20.000 maravedís \\
\hline Falcón, Juan & 25 & Labrador & 50 reales & Absuelto & 10.000 maravedís \\
\hline Falcón, Manuel & 33 & Labrador & 150 reales & $\begin{array}{l}2 \text { campañas como } \\
\text { soldado sin sueldo y } \\
4.000 \text { maravedís }\end{array}$ & $\begin{array}{l}4 \text { años de destierro y } \\
10.000 \text { maravedís }\end{array}$ \\
\hline Fernández, Juan & 42 & Herrero & 150 reales & $\begin{array}{l}2 \text { campañas como } \\
\text { soldado sin sueldo y } \\
4.000 \text { maravedís }\end{array}$ & 4.000 maravedís \\
\hline Fernández, Pedro & 40 & Herrero & 150 reales & $\begin{array}{l}2 \text { campañas como } \\
\text { soldado sin sueldo y } \\
4.000 \text { maravedís }\end{array}$ & 4.000 maravedís \\
\hline González, Diego & 32 & Regidor & 50 reales & Absuelto & $\begin{array}{l}6 \text { años en un Presidio } \\
\text { y } 60.000 \text { maravedís }\end{array}$ \\
\hline González, Juan & 60 & Ermitaño & 50 reales & Absuelto & 4.000 maravedís \\
\hline $\begin{array}{l}\text { Gutiérrez Barbado, } \\
\text { Juan }\end{array}$ & 35 & Labrador & 50 reales & Absuelto & 20.000 maravedís \\
\hline $\begin{array}{l}\text { Gutiérrez Cantón, } \\
\text { Pedro }\end{array}$ & 40 & Labrador & 200 reales & $\begin{array}{l}4 \text { años de Presidio y } \\
4.000 \text { maravedís }\end{array}$ & $\begin{array}{l}4 \text { años en un Presidio } \\
\text { y } 20.000 \text { maravedís }\end{array}$ \\
\hline $\begin{array}{l}\text { Gutiérrez Mozarro, } \\
\text { Pedro }\end{array}$ & 50 & Labrador & 60 reales & $\begin{array}{l}2 \text { años de destierro y } \\
4.000 \text { maravedís }\end{array}$ & 4.000 maravedís \\
\hline $\begin{array}{l}\text { Gutiérrez Pedruelo, } \\
\text { Diego }\end{array}$ & 56 & Labrador & 60 reales & $\begin{array}{l}2 \text { años de destierro y } \\
4.000 \text { maravedís } \\
\text { (fugado) }\end{array}$ & $\begin{array}{l}2 \text { años de destierro y } \\
10.000 \text { maravedís }\end{array}$ \\
\hline Gutiérrez, Celedón & 27 & Labrador & 60 reales & $\begin{array}{l}2 \text { años de destierro y } \\
4.000 \text { maravedís } \\
\text { (Preso en la villa) }\end{array}$ & $\begin{array}{l}4 \text { años en un Presidio } \\
\text { y } 20.000 \text { maravedís }\end{array}$ \\
\hline Gutiérrez, Manuel & 27 & Labrador & 200 reales & $\begin{array}{l}4 \text { años de Presidio y } \\
4.000 \text { maravedís }\end{array}$ & $\begin{array}{l}2 \text { años de destierro y } \\
10.000 \text { maravedís }\end{array}$ \\
\hline Gutiérrez, Pedro & 25 & Labrador & 50 reales & Absuelto & $\begin{array}{l}4 \text { años en un Presidio } \\
\text { y } 20.000 \text { maravedís }\end{array}$ \\
\hline
\end{tabular}




\begin{tabular}{|c|c|c|c|c|c|}
\hline NOMBRE & Edad & OFICIO & COSTAS & $\begin{array}{c}\text { SENTENCIAS 1a } \\
\text { INSTANCIA (1663) }\end{array}$ & $\begin{array}{c}\text { SENTENCIAS EN } \\
\text { APELACIÓN (1679) }\end{array}$ \\
\hline $\begin{array}{l}\text { Jiménez Melonares, } \\
\text { Pedro }\end{array}$ & 39 & Labrador & 60 reales & $\begin{array}{l}2 \text { años de destierro y } \\
4.000 \text { maravedís }\end{array}$ & 4.000 maravedís \\
\hline $\begin{array}{l}\text { Jiménez Patilla, } \\
\text { Francisco }\end{array}$ & 64 & Labrador & 60 reales & $\begin{array}{l}2 \text { años de destierro y } \\
4.000 \text { maravedís } \\
\text { (Preso en la villa) }\end{array}$ & $\begin{array}{l}4 \text { años de destierro y } \\
10.000 \text { maravedís }\end{array}$ \\
\hline $\begin{array}{l}\text { Jiménez Patilla, } \\
\text { Pedro }\end{array}$ & 28 & Labrador & 150 reales & $\begin{array}{l}2 \text { campañas como } \\
\text { soldado sin sueldo y } \\
4.000 \text { maravedís }\end{array}$ & $\begin{array}{l}2 \text { años de destierro y } \\
8.000 \text { maravedís }\end{array}$ \\
\hline Jiménez Penco, Juan & 42 & Labrador & 200 reales & $\begin{array}{l}4 \text { años de Presidio y } \\
4.000 \text { maravedís }\end{array}$ & $\begin{array}{l}4 \text { años en un Presidio } \\
\text { y } 20.000 \text { maravedís }\end{array}$ \\
\hline Jiménez Tarija, Juan & 30 & Labrador & 200 reales & $\begin{array}{l}4 \text { años de Presidio y } \\
4.000 \text { maravedís }\end{array}$ & $\begin{array}{l}4 \text { años en un Presidio } \\
\text { y } 20.000 \text { maravedís }\end{array}$ \\
\hline $\begin{array}{l}\text { Jiménez Tarija, } \\
\text { Miguel }\end{array}$ & 26 & Labrador & 60 reales & $\begin{array}{l}2 \text { años de destierro y } \\
4.000 \text { maravedís }\end{array}$ & 4.000 maravedís \\
\hline Marcilla, Antonio & 25 & Labrador & 200 reales & $\begin{array}{l}4 \text { años de Presidio y } \\
4.000 \text { maravedís }\end{array}$ & $\begin{array}{l}4 \text { años en un Presidio } \\
\text { y } 20.000 \text { maravedís }\end{array}$ \\
\hline Marcilla, Lázaro & 54 & Labrador & 200 reales & $\begin{array}{l}4 \text { años de Presidio y } \\
4.000 \text { maravedís }\end{array}$ & 4.000 maravedís \\
\hline Marín, Cristóbal & 58 & Labrador & 150 reales & $\begin{array}{l}2 \text { campañas como } \\
\text { soldado sin sueldo y } \\
4.000 \text { maravedís }\end{array}$ & $\begin{array}{l}4 \text { años en un Presidio } \\
\text { y } 20.000 \text { maravedís }\end{array}$ \\
\hline $\begin{array}{l}\text { Marín, Cristóbal } \\
\text { (menor) }\end{array}$ & 25 & Labrador & 50 reales & Absuelto & Absuelto \\
\hline Marín, Martín & 50 & Labrador & 50 reales & Absuelto & 20.000 maravedís \\
\hline Miranda, Antón & 26 & Labrador & 60 reales & $\begin{array}{l}2 \text { años de destierro y } \\
4.000 \text { maravedís } \\
\text { (preso en Madrid) }\end{array}$ & 4.000 maravedís \\
\hline $\begin{array}{l}\text { Moreno Berujo (o } \\
\text { Borujo), Francisco }\end{array}$ & 27 & Albañil & 60 reales & $\begin{array}{l}2 \text { años de destierro y } \\
4.000 \text { maravedís }\end{array}$ & 20.000 maravedís \\
\hline $\begin{array}{l}\text { Moreno } \\
\text { Esparraguera, } \\
\text { Francisco }\end{array}$ & 46 & Labrador & 200 reales & $\begin{array}{l}4 \text { años de Presidio y } \\
4.000 \text { maravedís }\end{array}$ & $\begin{array}{l}4 \text { años en un Presidio } \\
\text { y } 20.000 \text { maravedís }\end{array}$ \\
\hline Moreno, Francisco & 26 & Labrador & 150 reales & $\begin{array}{l}2 \text { campañas como } \\
\text { soldado sin sueldo y } \\
4.000 \text { maravedís }\end{array}$ & $\begin{array}{l}4 \text { años en un Presidio } \\
\text { y } 20.000 \text { maravedís }\end{array}$ \\
\hline Moreno, Gaspar & 53 & Labrador & 60 reales & $\begin{array}{l}2 \text { años de destierro y } \\
4.000 \text { maravedís }\end{array}$ & $\begin{array}{l}4 \text { años en un Presidio } \\
\text { y } 20.000 \text { maravedís }\end{array}$ \\
\hline Moreno, Juan & 25 & Labrador & 150 reales & $\begin{array}{l}2 \text { campañas como } \\
\text { soldado sin sueldo y } \\
4.000 \text { maravedís }\end{array}$ & $\begin{array}{l}4 \text { años de destierro y } \\
10.000 \text { maravedís }\end{array}$ \\
\hline Muñoz, Pedro & 65 & Labrador & 50 reales & Absuelto & Absuelto \\
\hline Ocón, José & 36 & Labrador & 200 reales & $\begin{array}{l}4 \text { años de Presidio y } \\
4.000 \text { maravedís }\end{array}$ & $\begin{array}{l}4 \text { años en un Presidio } \\
\text { y } 20.000 \text { maravedís }\end{array}$ \\
\hline
\end{tabular}




\begin{tabular}{|c|c|c|c|c|c|}
\hline NOMBRE & Edad & OFICIO & COSTAS & $\begin{array}{c}\text { SENTENCIAS 1a } \\
\text { INSTANCIA (1663) }\end{array}$ & $\begin{array}{l}\text { SENTENCIAS EN } \\
\text { APELACIÓN (1679) }\end{array}$ \\
\hline Ocón, Miguel & 50 & Labrador & 60 reales & $\begin{array}{l}2 \text { años de destierro y } \\
4.000 \text { maravedís }\end{array}$ & 4.000 maravedís \\
\hline Olloqui, Francisco & 37 & Mesonero & 50 reales & Absuelto & $\begin{array}{l}2 \text { años de destierro y } \\
10.000 \text { maravedís }\end{array}$ \\
\hline $\begin{array}{l}\text { Pastor Tocino, } \\
\text { Francisco }\end{array}$ & 56 & Labrador & 150 reales & $\begin{array}{l}2 \text { campañas como } \\
\text { soldado sin sueldo y } \\
4.000 \text { maravedís }\end{array}$ & 4.000 maravedís \\
\hline Pastor, José & 26 & Labrador & 150 reales & $\begin{array}{l}2 \text { campañas como } \\
\text { soldado sin sueldo y } \\
4.000 \text { maravedís }\end{array}$ & Absuelto \\
\hline $\begin{array}{l}\text { Pérez Mesonera, } \\
\text { Pedro }\end{array}$ & 24 & Labrador & 200 reales & $\begin{array}{l}4 \text { años de Presidio y } \\
4.000 \text { maravedís } \\
\text { (Preso en la villa) }\end{array}$ & 20.000 maravedís \\
\hline $\begin{array}{l}\text { Pérez Noguel, Juan } \\
\text { Francisco }\end{array}$ & $i$ & $\begin{array}{l}\text { Organista } \\
\text { y labrador }\end{array}$ & 150 reales & $\begin{array}{l}2 \text { campañas como } \\
\text { soldado sin sueldo y } \\
4.000 \text { maravedís } \\
\text { (Preso en Logroño) }\end{array}$ & 4.000 maravedís \\
\hline $\begin{array}{l}\text { Pérez Trevijano, } \\
\text { Domingo }\end{array}$ & 31 & Labrador & 200 reales & $\begin{array}{l}4 \text { años de Presidio y } \\
4.000 \text { maravedís } \\
\text { (Preso en la villa) }\end{array}$ & 20.000 maravedís \\
\hline Pérez, Catalina & 25 & & 50 reales & Absuelta & Absuelta \\
\hline Pérez, Diego & 27 & Labrador & 200 reales & $\begin{array}{l}4 \text { años de Presidio y } \\
4.000 \text { maravedís }\end{array}$ & $\begin{array}{l}4 \text { años en un Presidio } \\
\text { y } 20.000 \text { maravedís }\end{array}$ \\
\hline Pérez, Pedro & 28 & Sastre & 60 reales & $\begin{array}{l}2 \text { años de destierro y } \\
4.000 \text { maravedís }\end{array}$ & $\begin{array}{l}4 \text { años en un Presidio } \\
\text { y } 20.000 \text { maravedís }\end{array}$ \\
\hline $\begin{array}{l}\text { Préjano (o Resano), } \\
\text { Juan }\end{array}$ & 39 & Labrador & 50 reales & Absuelto & $\begin{array}{l}4 \text { años en un Presidio } \\
\text { y } 20.000 \text { maravedís }\end{array}$ \\
\hline Rodríguez, Baltasar & 46 & Labrador & 50 reales & Absuelto & 4.000 maravedís \\
\hline $\begin{array}{l}\text { Roldán Cogote, } \\
\text { Martín }\end{array}$ & 46 & Labrador & 200 reales & $\begin{array}{l}4 \text { años de Presidio y } \\
4.000 \text { maravedís }\end{array}$ & $\begin{array}{l}4 \text { años en un Presidio } \\
\text { y } 20.000 \text { maravedís }\end{array}$ \\
\hline Roldán, Martín & 36 & Alcalde & 50 reales & Absuelto & $\begin{array}{l}6 \text { años en un Presidio } \\
\text { y } 60.000 \text { maravedís }\end{array}$ \\
\hline Rubio, Cosme & 32 & Sastre & 200 reales & $\begin{array}{l}4 \text { años de Presidio y } \\
4.000 \text { maravedís } \\
\text { (Preso en la villa) }\end{array}$ & $\begin{array}{l}4 \text { años en un Presidio } \\
\text { y } 20.000 \text { maravedís }\end{array}$ \\
\hline Rubio, Manuel & 29 & Sastre & 200 reales & $\begin{array}{l}4 \text { años de Presidio y } \\
4.000 \text { maravedís } \\
\text { (Preso en la villa) }\end{array}$ & $\begin{array}{l}4 \text { años en un Presidio } \\
\text { y } 20.000 \text { maravedís }\end{array}$ \\
\hline Rueda, Pedro & 25 & Labrador & 200 reales & $\begin{array}{l}4 \text { años de Presidio y } \\
4.000 \text { maravedís }\end{array}$ & $\begin{array}{l}4 \text { años en un Presidio } \\
\text { y } 20.000 \text { maravedís }\end{array}$ \\
\hline $\begin{array}{l}\text { Ruiz de Bucesta, } \\
\text { Miguel }\end{array}$ & 43 & Alcalde & 50 reales & Absuelto & Absuelto \\
\hline
\end{tabular}




\begin{tabular}{|c|c|c|c|c|c|}
\hline NOMBRE & Edad & OFICIO & COSTAS & $\begin{array}{l}\text { SENTENCIAS 1a } \\
\text { INSTANCIA (1663) }\end{array}$ & $\begin{array}{l}\text { SENTENCIAS EN } \\
\text { APELACIÓN (1679) }\end{array}$ \\
\hline Ruiz Escorza, Martín & 31 & Labrador & 150 reales & $\begin{array}{l}2 \text { campañas como } \\
\text { soldado sin sueldo y } \\
4.000 \text { maravedís }\end{array}$ & $\begin{array}{l}4 \text { años de destierro y } \\
10.000 \text { maravedís }\end{array}$ \\
\hline Ruiz Pelate, Miguel & 30 & Labrador & 200 reales & $\begin{array}{l}4 \text { años de Presidio y } \\
4.000 \text { maravedís }\end{array}$ & $\begin{array}{l}4 \text { años en un Presidio } \\
\text { y } 20.000 \text { maravedís }\end{array}$ \\
\hline $\begin{array}{l}\text { Ruiz Pérez Tarija, } \\
\text { Juan }\end{array}$ & 46 & Labrador & & $\begin{array}{l}\text { Absuelto } \\
\text { (Preso en Madrid) } \\
\end{array}$ & 4.000 maravedís \\
\hline Ruiz Roldán, Juan & 39 & Labrador & 50 reales & Absuelto & 4.000 maravedís \\
\hline Ruiz, Antonio & 30 & Carretero & 60 reales & $\begin{array}{l}2 \text { años de destierro y } \\
4.000 \text { maravedís } \\
\text { (Preso en la villa) }\end{array}$ & 4.000 maravedís \\
\hline Ruiz, Domingo & 26 & Labrador & 150 reales & $\begin{array}{l}2 \text { campañas como } \\
\text { soldado sin sueldo y } \\
4.000 \text { maravedís }\end{array}$ & 8.000 maravedís \\
\hline Ruiz, Miguel & 40 & Carretero & 60 reales & $\begin{array}{l}2 \text { años de destierro y } \\
4.000 \text { maravedís } \\
\text { (Preso en la villa) }\end{array}$ & 4.000 maravedís \\
\hline Sáenz, Francisca & - & & 60 reales & & \\
\hline Sánchez, Antonio & 30 & Zapatero & 200 reales & \begin{tabular}{|l}
4 años de Presidio y \\
4.000 maravedís \\
(Preso en la villa)
\end{tabular} & $\begin{array}{l}4 \text { años en un Presidio } \\
\text { y } 20.000 \text { maravedís }\end{array}$ \\
\hline $\begin{array}{l}\text { Sanz Inestrillas, } \\
\text { Francisco }\end{array}$ & - & & & $\begin{array}{l}2 \text { años de destierro y } \\
4.000 \text { maravedís } \\
\end{array}$ & 4.000 maravedís \\
\hline Soldevilla, Juan & 30 & Labrador & 200 reales & $\begin{array}{l}4 \text { años de Presidio y } \\
4.000 \text { maravedís }\end{array}$ & $\begin{array}{l}4 \text { años en un Presidio } \\
\text { y } 20.000 \text { maravedís }\end{array}$ \\
\hline Virto, Juan Francisco & 15 & $\begin{array}{l}\text { Hijo del } \\
\text { boticario }\end{array}$ & 50 reales & Absuelto & Absuelto \\
\hline
\end{tabular}

Veinte vecinos, aquellos contra los que había cargos más graves, fueron condenados a penas de entre 2 y 4 años de presidio, que no era exactamente una pena de cárcel, sino que los reos eran enviados a una de las fortalezas de frontera -llamadas presidios-, como Orán, Melilla, Ceuta, Pamplona, Jaca, Fuenterravía, etc., donde debían prestar servicio como trabajadores forzados o como soldados sin sueldo durante el tiempo que estipulase la condena. Otros 12 fueron condenados a servir durante varios años como soldados sin sueldo en el Ejército, una de las muchas políticas puestas en marcha por la Corona para suplir la práctica ausencia de soldados voluntarios para los Tercios. Por último, otros 11 fueron condenados a penas de destierro. Paralelamente, a todos los vecinos que fueron considerados culpables - un total de 49- se les impuso 196.000 maravedís de multa, a razón de 117 reales por cabeza, sanción sor- 
prendentemente liviana ${ }^{34}$. Por último, las costas que se les imputaron ascendieron en total a 7.690 reales.

Quienes no fueron molestados fueron los curas de la Parroquia, a pesar de que sobre alguno de ellos había más que indicios sobre su implicación. Puede resultar sorprendente, pero procesarles hubiese sido, para empezar, ilegal, pues la Iglesia tenía jurisdicción propia y tribunales independientes, de tal manera que el rey tendría que haber solicitado la intervención del Obispo de Calahorra, lo cual hubiese generado sin duda nuevos e innecesarios problemas políticos y complicado enormemente el asunto.

Las sentencias del pesquisidor, teniendo en cuenta la legislación vigente y la jurisprudencia sobre otros hechos parecidos sucedidos por estas fechas, no fueron severas, en coherencia con la actitud conciliadora que en estos casos solía adoptar el Consejo de Castilla. Pero hay otros dos detalles muy interesantes: el primero es que entre los procesados está una de las víctimas del motín, nada menos que Miguel Ruiz de Bucesta, hermano de Celedón, el jefe de la familia huido a Alfaro, y que circunstancialmente ese año era alcalde ordinario por el estamento hidalgo. Fue absuelto, por supuesto, pero le cobraron 50 ducados de costas: era su probablemente no deseada contribución al enorme interés del Consejo de Castilla por transmitir imagen de imparcialidad ante la población de Aldeanueva.

El segundo detalle es todavía más interesante: las sentencias fueron apeladas por ambas partes ante el Consejo de Castilla y, por tanto, de momento no tenían que ejecutarse, y la historia ulterior del proceso deja bien a las claras la intencionalidad política conciliadora que éstas tenían para la Corona. En 1678, nada menos que 15 años después de la sentencia del pesquisidor, el Superintendente de Presidios, siempre necesitado de soldados para las fortalezas puestas a su cargo, ordenó por su cuenta al Alcalde Mayor de Alfaro que procediese a detener a los vecinos condenados a penas de presidio, pero estos le recibieron reunidos en un amenazador concejo abierto y no se atrevió a arrestar a nadie. Sin embargo, la iniciativa del Superintendente reactivó un ya olvidado asunto y al año siguiente, en 1679, se designaron tres oidores en el Consejo de Castilla para que instruyesen de una vez la apelación.

Pero habían pasado muchos años, ya habían fallecido 18 de los condenados y ni siquiera seguía vivo el principal afectado por los sucesos, don Juan Manuel Íñiguez de Arnedo $^{35}$, que había muerto prematuramente en 1667. Cuando el Consejo expidió definitivamente la ejecutoria de la apelación (1680) los difuntos ascendían ya a 24 y, además, los vecinos hicieron uso del recurso de segun-

34. Eso debió pensar también el Consejo de Castilla años después, dado que elevó las multas hasta los 920.000 maravedís, es decir, que las multiplicó por más de cuatro. En cualquier caso, como explicamos más adelante, nunca llegaron a pagarse.

35. Cfr. José Rojas y Contreras, Historia del Colegio..., op. cit., p. 427. 
da suplicación, es decir, que presentaron una segunda apelación. Pero seguía sin haber prisas y hubo que esperar hasta 1683 (20 años después del motín) para que se aprobase admitir a trámite la apelación de los vecinos, momento en que volvió designarse otra nueva Sala con órdenes de instruir el caso íntegramente desde el principio: nunca llegó a hacerse, de modo que ninguno de los condenados cumplió pena alguna.

De haber querido, el Consejo podría haber dictado la sentencia de apelación en unas semanas -cuando era políticamente necesario, así lo hacía-, pero algo aconsejó no tensar más la cuerda con la población, pues llegaron inquietantes noticias sobre lo que estaba sucediendo en Aldeanueva. Celedón Ruiz de Bucesta y sus parciales, refugiados ahora en Rincón de Soto, lo relataban así al Consejo de Castilla:

Desde 26 de mayo [de 1663] acá que se levantó el tumulto, hasta hoy 21 de febrero de 64, todas las noches no han cesado de arcabucear y apedrear las ventanas y casas de los ausentes y las de sus hermanos y afectos, yendo cantando muchas infamias en descrédito grande de los contenidos, tratándoles a las doncellas hijas suyas y de los demás afectos palabras ignominiosas en descrédito de su buena opinión ${ }^{36}$

No les faltaban razones para lamentarse, pues en cuanto el juez pesquisidor abandonó el pueblo, los amotinados se adueñaron de la situación y el primer objetivo de la población fue directamente arruinar económicamente a sus convecinos exiliados, considerados como traidores a la comunidad:

No contentos ni satisfechos con tener a mis partes ausentes y fugitivos de su patria, desterrados della y fuera de sus casas y quedado con sus haciendas y quitándoles más de decientas cargas de mies, e más a campana tañida, convocando a los vecinos para que fuesen a vendimiar las viñas de mis partes y cogido dellas más de ciento e cincuenta cargas de uva y trescientas e cincuenta y más de cabezas de ganado, maltratándoles los pastores y zagales y arcabuceándoles y atándolos

Los jornaleros o pastores que osaban trabajar para los exiliados eran objetivo inmediato de los vecinos amotinados, sucediendo decenas de pequeños incidentes, que normalmente no iban más allá de unos empujones y unas cuantas amenazas, pero que bastaron para aislar económicamente a las familias huidas. Cuando alguno de ellos osó acercarse a las inmediaciones del pueblo -los amotinados parece que tenían vigías permanentes en puntos estratégicos-, la

36. Para estos hechos posteriores al motín utilizo el documento publicado por Francisco Javier Vicuña Ruiz en "El Motín de Aldeanueva", en Berceo, nº 102, 1982, pp. 71-102. 
respuesta fue mucho más contundente, como les sucedió, por ejemplo, a Juan y Miguel Marín, el 3 de enero de 1664 (casi siete meses después del motín):

Teniendo noticia que don Juan y don Miguel Marín estaban viendo a unos podadores que podaban sus viñas... salieron al puesto y sitio donde estaban a manera y forma de escuadrón armado con sus arcabuces, mosquetes y otras armas de fuego, dispuestas a modo de pelea, y los cercaron y rodearon por tres partes y cogieron en medio y les tiraron muchos arcabuzazos, carabinazos y mosquetazos... y habiéndosele caído a don Juan Marín la montera, la cogieron, y como despojo del triunfo de haberlos arcabuceado, la llevaron con grande algazara y entraron en la dicha villa diciendo a voces: “¡Putas de la plaza, la montera traemos de aquel ladrón de Juan Marín, veisla aquí! juzgamos traer la cabeza, y pues no pudo ser, pague la gorra lo que había de pagar aquella" $Y$ poniéndola en una almena y bola del fosal que está en la plaza pública, la arcabucearon y después de hecha una criba la echaron al tejado de la iglesia

También fueron asaltadas sus propiedades y bienes inmuebles en el pueblo y sus alrededores, pero -como solía ser usual en estos casos- respetando los domicilios propiamente dichos:

Los dichos acusados han entrado por fuerza en las casas de mis partes descerrajando las puertas de ellas y sus graneros, y sacádoles más de mil fanegas de trigo y entrado en sus heredades y viñas y despedazádoles y cortádoles muchos árboles fructíferos y herido y maltratado muchas cabalgaduras mayores.

Las agresiones directas contra los huidos llegaron a tal punto que, tras enterarse de que varios de ellos se habían refugiado en el cercano Rincón de Soto, una partida de vecinos armados penetró en este pueblo con intenciones nada amistosas:

los dichos acusados por el mes de junio deste año... Ilegaron al dicho lugar de Rincón de Soto en busca de mi partes para matarles y alborotando dijeron a grandes voces: “¡Caigan, mueran estos traidores! ¿Para qué los consienten en este lugar?" Y a no haber salido la justicia del dicho lugar con otros vecinos hobieran ejecutado su intento

Todavía en agosto la campaña de acoso económico estaba en pleno apogeo y se impedía a los huidos del pueblo cobrar las rentas de las tierras que tenían arrendadas. Por estas fechas, por ejemplo, tuvo la osadía de entrar en el pueblo Ventura Zugasti, con la intención de cobrar las rentas que le debían sus aparceros:

Luego que tuvieron noticia de su llegada, con sus arcabuces, pistolas y otras armas de fuego fueron a la casa de Martín Roldán, alcalde, y se 
juntaron en ella. $Y$ juntos y confederados todos y de un consejo deliberado acordaron que cada uno con un palo de hasta una vara salieran por toda la villa en busca del dicho Ventura de Zugasti, y donde le hallaran lo mataran a palos. Y de no haberle dado aviso con tiempo José Matute, lo hubieran conseguido

En febrero de 1664 se presentó en el pueblo Fray Miguel Gutiérrez, Provincial de los Franciscanos y natural de Aldeanueva, con la intención de devolver la "paz y concordia entre los vecinos" -o eso dijo venir a hacer-, pero cometió el error de hospedarse en la casa de uno de los exiliados, Juan Marín, y ello fue interpretado por la población como signo de que estaba a sus órdenes o por los menos de su parte, así que la respuesta fue de nuevo violenta:

Se amotinaron y concitaron... y fueron a la casa donde estaba el dicho religioso y su compañero, diciendo a grandes voces "¡Caiga este mal fraile, que es un traidor! ¡Caiga, muera! ¡Quemémosle la casa! ¡Quemémosle! ¡Levantémosle la casa con pólvora!"

El ataque a este fraile no fue algo excepcional, varios clérigos del pueblo tuvieron que huir atropelladamente y buscar refugio en otras poblaciones tras el motín para evitar las represalias y los que intentaron regresar, siquiera de visita, fueron atacados por la población, incluso uno recibió una cuchillada ${ }^{37}$.

Durante meses la villa estuvo en un estado de sublevación permanente, en el que alternaba un ambiente de terror o de fiesta, según en qué bando se estuviese, pues si durante el día era tiempo de agresiones y amenazas, por la noche llegaba la fiesta y las canciones de ronda en torno a las casas de los huidos y de sus amigos, como denunciaba el procurador de los huidos ante el Consejo de Castilla:

Los dichos acusados, en todo el tiempo que han vivido a sus anchuras después que se amotinaron, de día han hablado muy mal de mis partes y sus familias, injuriándoles grave y atrozmente, y cantando de noche muchos cantares y coplas ignominiosas en su oprobio y menosprecio, $y$ de ordinario han andando con armas y bocas de fuego... y disparándolos con tanto ruido, como si la villa fuese plaza de armas.

37. Entre los clérigos se repitió la división social que hubo entre los vecinos laicos, según los documentos del Pesquisidor, hubo 6 curas de algún modo implicados en el motín -Pedro Muñoz, Miguel Jiménez, Francisco Vergara, Diego Gutiérrez, Manuel Ulloqui y Francisco Ulloqui-, mientras que un total de cuatro sufrieron agresiones de los amotinados: Bernardo Pérez de Medrano, Isidro Marcilla, Diego Marín y Manuel Alonso. Archivo Histórico Nacional, Consejos, leg. 33.987. 
Este era el ambiente social que había en Aleanueva desde antes de dictarse las sentencias en primera instancia, así que el Consejo optó por aplicar una estrategia apaciguadora: no publicar las sentencias en apelación, lo cual impedía que de momento se ejecutase ninguna de ellas, y no mover un dedo para castigar los graves tumultos que se produjeron en los meses posteriores, todo para no encolerizar todavía más a la población.

Desconocemos en qué fecha los huidos -que ya no sólo eran los Bucesta, los Marín y los Zugasti, sino buena parte de sus amigos y parientes-, pudieron regresar a sus casas ni en qué condiciones lo hicieron, pero desde luego el resto de su vida no se pareció en nada al futuro de poder omnímodo que acariciaron al tramar la venta de Aldeanueva a don Juan Manuel Íñiguez de Arnedo. Un indicio es que todavía en 1667, cuatro años después del motín, los pecheros del pueblo se negaban a reconocer preeminencia alguna a los hidalgos en los actos públicos, es más, eran ellos quienes encabezaban las comitivas oficiales ${ }^{38}$; o en 1671, cuando lo hidalgos -con Sebastián Ruiz de Bucesta a la cabeza-, denunciaban que los pecheros se negaban a dejarles participar en los repartimientos de las cuotas fiscales que los vecinos habían de pagar cada año, y que lo hacían ellos solos, con los efectos que podemos imaginarnos ${ }^{39}$. En 1670, una carta de poder firmada por los miembros del estamento hidalgo, con Celedonio Ruiz de Bucesta ya residiendo en el pueblo, nos da una idea de cuál era la situación política en la villa:

Les dan poder [a sus procuradores] para que hagan las demandas que sean necesarias contra el estado general, especialmente en un pleito de exenciones y preeminencias que el estado de hombres buenos pretende con su estado sobre la precedencia de los regidores, y porque el estado general ha contravenido las ejecutorias que tienen ganadas sobre su exención y libertad de contribuir, ni coger padrón, ni derrama alguna de los efectos reales con que esta villa sirve a su majestad. Y para que... no pueda juntar ayuntamiento, ni concejo, ni junta, sin hallarse presentes el alcalde y demás oficiales del estado de hijos de algo, ni puedan hacer en su estado ningún repartimiento, aunque sea de los que solo tocan a su estado, sin que asistan a ello los oficiales del estado de hijosdalgo. También les dan poder para que en su nombre pidan que todas las personas de su estado de hijos de algo tengan asiento y mano derecha en los actos públicos, iglesia, procesiones y demás partes donde concurrieren con el estado general, de manera que siempre tenga la mano derecha el estado de hijos de algo. Además, porque en los repartimientos que se hacen entrambos estados los hijos de algo van grabados y cargados con exceso en los repartimientos por concurrir a ellos solamente una persona del y

38. Archivo de la Chancillería de Valladolid, Registro de Ejecutorias, Caja 2923.49.

39. Archivo de la Chancillería de Valladolid, Registro de Ejecutorias, Caja 2945.58. 
del general tres, para que pidan sean repartidos dos de cada estado, y ansimismo pidan que en todas las ocasiones que hubiere procesiones y saliere el Santísimo Sacramento, las antorchas, palio y demás insignias, se les hayan de comunicar primero a los miembros estado de hijos dalgo ${ }^{40}$

Lo interesante no es sólo que los hidalgos viesen ninguneados sus privilegios, sino observar cómo tuvieron que recurrir a la Chancillería de Valladolid una y otra vez para que semejante cosa no sucediera, es decir, que ya no eran capaces de hacerse obedecer por si mismos, algo muy significativo para imaginar los efectos que tuvo el motín y el año de revueltas que le siguió sobre la vida cotidiana y las relaciones de poder en Aldeanueva.

El colofón de la política conciliadora que había seguido el Consejo de Castilla desde el día del motín llegó el 13 de febrero de 1664, cuando el rey aceptó la oferta de Aldeanueva para anular la venta ya realizada y permitió que los vecinos tanteasen la jurisdicción, es decir, comprasen su propio pueblo al rey por una cantidad algo superior a la que había pagado su efímero Señor, de tal modo que la Corona obtuviese algún beneficio con la operación. Nuevamente los vecinos se organizaron para anular definitivamente la compra que había hecho Juan Manuel Î́niguez, quien, por supuesto, todavía era nominalmente Señor de "Arnedo de Ebro", como pomposamente habían rebautizado al pueblo. Ahora, con el grupo de los Bucesta huido o aterrorizado, las dificultades se redujeron notoriamente, pero en todo ello jugó un papel clave cierto cura del pueblo: el Licenciado Martín Suberto, ya implicado en el movimiento desde los primeros momentos.

Fue él quien viajó a la Corte para hacer formalmente la oferta de tanteo al Consejo de Hacienda y quien, tras adelantar 1,686.000 maravedís de plata y 680.000 maravedís de vellón regresó al pueblo con el ansiado Real Decreto que anulaba la venta al Señor bajo el brazo. El pueblo asumía pues una deuda con el clérigo de unos 2 millones de maravedís de plata y otra pendiente con la Corona de algo más de esa cantidad. Para pagar esas deudas se recurrió a Gil Velázquez, regidor de Logroño y el mercader más rico de la ciudad, quien les prestó 7.000 ducados de plata, cómo devolvieron esta cantidad es ya otra historia, que por cierto, Ilegaría hasta 1924, cuando una sentencia del Tribunal Supremo anulaba la deuda de 33.000 pesetas que todavía arrastraba el pueblo con los remotos herederos de Gil Velázquez.

Un 20 de marzo de 1664 se expedía el Real Decreto que, por fin, otorgaba la titularidad de Aldeanueva a sus vecinos, segregando la población de Calahorra y ascendiéndola a la categoría de villa con jurisdicción propia. También se le volvería a cambiar el nombre de Arnedo de Ebro por Aldeanueva de Ebro, el que todavía hoy tiene. Curiosamente, el Alcalde Mayor que había nombrado

40. AHPLo., Legajo 6.364, 1670, Folios 75-76, documento cedido por Da Sara Bustos. 
el Señor, a quien nadie obedecía desde hacía tiempo, se negó a abandonar el cargo pese a la nueva situación, de tal manera que hasta el 3 de junio de 1665 se mantuvo obstinadamente en su puesto.

Los tiempos en que sucedieron todos estos hechos nos hablan de una CastiIla empobrecida y crecientemente despoblada, fenómeno del que no se había librado Aldeanueva hasta entonces, que en 1583 tenía 288 vecinos con reservas de trigo en sus casas ${ }^{41}$-el número total sería muy superior-y todavía en $1611^{42}$ se decía que tenía 400 vecinos, pero en 1663 sólo pudieron contarse $275^{43}$. La segregación parece que no le fue mal, al menos si comparamos su evolución con la de las otras aldeas de Calahorra: Aldeanueva en 1697, con 374 vecinos, casi había recuperado la población que tenía a comienzos de siglo, mientras que en el mismo periodo (1611-1697) la ciudad de Calahorra había pasado de 1.100 vecinos a 860, Rincón de Soto de 250 a 120 y Murillo de Calahorra de 130 a $48^{44}$. Calahorra no recuperaría la población que tenía a finales del XVI hasta mediados del XVIII ${ }^{45}$, mientras que Aldeanueva lo había conseguido apenas treinta años después de segregarse.

41. A.H.N., Consejos, legajo 33.112.

42. A.H.N., Consejos, legajo 24.814. Para 1637 la población ya había iniciado el declive, contabilizándose 387 vecinos, que se reducirían a 350 en 1640. Cfr. Ruiz de Bucesta, Manuel, "Aldeanueva...", art. cit. pp. 13-16; y Catastro de Ensenada. Copias de títulos y privilegios, AHPLR, Caja 31, vol. 32.

43. A.H.N., Consejos, legajo 33.112.

44. A.H.N., Consejos, legajo 251-1.

45. Cfr. Gurría, Pedro, "La población de Calahorra durante el Antiguo Régimen demográfico", en Kalakorikos, 2012, no 12, pp. 11-30. 